\title{
Discourse on Seismotectonics of Nepal Himalaya and Vicinity:Appraisal to Earthquake Hazard
}

\author{
D. Shanker ${ }^{1, *}$, Harihar Paudyal ${ }^{2}$, H. N. Singh ${ }^{3}$ \\ ${ }^{1}$ Department of Earthquake Engineering, Indian Institute of Technology Roorkee, Roorkee, Uttarakhand, 247667, India \\ ${ }^{2}$ Department of Physics, Birendra Multiple Campus, Tribhuvan University, Bharatpur, Chitwan, Nepal \\ ${ }^{3}$ Department of Geophysics, Banaras Hindu University, Varanasi, 221005, India
}

\begin{abstract}
An extremely complex geotectonic framework coupled with high seismic status has made the Central part of the Himalayas, a destination to study the complex inter-continental collision processes. The collision also caused large scale deformation and high seismicity of vast region of colliding continents. This region displays all major tectonic features of the Himalayan mobile belt and is seismically one of the active regions in the Himalayan arc. Focal mechanism solutions bear out a multifaceted pattern. Thrust environment is dominant in the Western and Central Nepal region, whereas, in the Eastern Nepal, it is a amalgamation of thrust and strike-slip with large thrust mechanism. In western region thrust faulting coupled with shallow dip nodal planes reflects the Indian lithosphere is under-thrusting at a shallow angle. Here, the crustal shortening in north- south direction in which earthquakes is generated due to northward compression. The shortening was accommodated by development of various NW-SE trending structures like Himalayan Arc MCT (Main Central Thrust), MBT (Main Boundary Thrust); MFT (Main Frontal Thrust). The observed change in the faulting pattern in the eastern parts of the thrust zone may indicate substantial movement along the transverse faults, as compared to that of the western region with the changes in the deep crustal structure. The thrusting decreases rapidly with increasing focal depth and deformation occur due to strike-slip motion at greater depths. This may investigative of an unstable state of the upper mantle leading to a rapid deformation in the presence of high degree of thermal regime. The composite stereographic projection of the compression and tension axes suggest a shallow compressive stress, dipping N-S to NE-SW in Western Nepal whereas it is N-S to NNE-SSW direction of compression at a shallow angle in Eastern Nepal. The region produced a number of devastating events in the past. Central Himalaya comprising Nepal and its adjoining region in which different types of faulting patterns exist have signatures of a great earthquake in 1934 and a number of large events thereafter, advocate serious seismic hazard in the region.
\end{abstract}

Keywords Fault-Plane Solution, Collision Processes, Stress Pattern, Nepal Himalaya, Stereographic Projection

\section{Introduction}

As the word Seismotectonics is concern, it is the analysis of seismological, geophysical, geodetic and geological data to deduce the tectonic frame work of a region. Such a study throws significant light on the nature of tectonic processes taking place in a region. The focal mechanism solution or fault-plane solution often called Beach ball diagrams are a very commonly used way of graphically representing the fault geometry and slip direction of an earthquake. The fault- plane solution yields information about a fault and the direction of movement due to an earthquake which provides an instantaneous picture of tectonic movement. It describes the mode in which the seismic energy released at the

* Corresponding author:

dayasfeq@iitr.ernet.in (D. Shanker)

Published online at http://journal.sapub.org/geo

Copyright (C) 2011 Scientific \& Academic Publishing. All Rights Reserved hypo-central zone of an earthquake and facilitates to understand the physical and the tectonic conditions of a seismically active region. It is assumed that a single earthquake represents the stress condition at the hypocenter and the compression and tension axes of a single fault-plane solution denote more or less the principal directions of the greatest and the least stress component.

The central sector of the Himalaya comprising of Nepal and its adjoining region is considered in the present study to understand the current status of the seismic activity tectonics and geodynamic processes using the fault- plane solutions. The region has a complex tectonic history (Upreti, 1999; Hodges, 2000) with highly deformed upper crust and displays all major tectonic features of the Himalayan mobile belt. The region is known for its high seismic activity in which the great earthquake of 1934 (M 8.4) of Bihar-Nepal border region and a number of large earthquakes of magnitude $M \geq 6.0$ have occurred during the last 100 years. The seismicity of the region is fundamentally associated with 
the MBT and also with a number of thrusts, normal and transverse faults. The main Himalayan seismic belt is mostly confined within the MCT and the MBT (Ni and Barazangi, 1984). Seismic activities in the Nepal Himalaya region are confined mostly in the upper crustal portion; whereas the clusters of a few intermediate events have been found between the MBT and the MCT in the Western Nepal region.

A total of eighty-three fault-plane solutions were used to infer the prevailing stress pattern and the geodynamic processes in the Himalayan collision zone including twenty-three new fault-plane solutions, determined in the present study, and the remaining sixty solutions compiled from the published literatures (Rastogi, 1974; Chandra, 1978; Singh and Gupta, 1980; Baranowski et al., 1984; Ni and Barazangi, 1984; Zhu and Helmberger, 1996; Paudyal et al., 2008; Paudyal et al., 2010; Paudyal, 2011; Centroid Moment Tensor (CMT) solution). Rastogi (1974) observed a thrust faulting environment of earthquakes with a shallow dipping nodal plane. This has been found to be consistent with the underthrusting of Indian plate towards north-northeast beneath the Himalaya; the determination was based on seven fault-plane solutions using P-wave first motion data. Chandra (1978) determined eighteen fault-plane solutions using WWSSN P-wave first motion data by plotting on an equal area projection of lower focal hemisphere. He observed that the thrust type faulting is prevalent in the Central Himalaya and confirmed that the underthrusting of Indian plate towards the north along the Himalayan arc has occurred. Singh and Gupta (1980) used $\mathrm{P}$-wave first motion data as well as surface wave polarization angle and determined the source dynamics of 1934 great earthquake. They observed thrust and strike slip components and inferred that there is underthrusting of Indian plate towards southwest. The high stress drop associated with 1934 earthquake was interpreted in terms of high tectonic stress prevailing in the region. Using $\mathrm{P}, \mathrm{pP}$ and $\mathrm{sP}$ phases recorded at long-period seismographs of WWSSN, Molnar and Chen (1983) determined sixteen fault-plane solutions of Tibetan region and observed that there is a presence of a combination of normal and strike-slip faulting with $\mathrm{T}$-axes trending approximately east-west. Baranowski et al. (1984) modified the earlier fault-plane solutions of nine earthquakes in the Himalayan arc by comparing the synthetic seismogram with long period body waves and pointed out that there is a coherent underthrusting of Indian plate beneath the Lesser Himalaya in the eastern half of the arc. They inferred that slip vectors are locally perpendicular to the Himalayan mountain range with very gentle plunge in the eastern section and more steeply in the western section.

$\mathrm{Ni}$ and Barazangi (1984) determined six solutions using P-wave first motion and S-wave polarization recorded on long period instruments of WWSSN, and observed the shallow angle north dipping thrust environment in the Himalayan collision zone. Considering these observations, they concluded that this zone separates the underthrusting Indian plate from Lesser Himalayan crustal block which appears to define a part of the detachment. Zhu and Helmberger (1996) used broadband record of regional distance and $\mathrm{pP}$ and $\mathrm{sP}$ phases by waveform modelling for three small earthquakes situated in the north of the Higher Himalaya, and also observed strike-slip mechanism with some component of normal faulting showing roughly north-south compression and east-west extension. Paudyal et al. (2008) used $\mathrm{P}$ wave first motion data and compared the faulting pattern of Western and Eastern Nepal. Paudyal et al. (2010) studied detail seismotectonic mechanism of western Nepal and adjoining region using twelve new solutions determined from $P$ wave data. The process for the determination of the fault-plane solutions is uniform in CMT solutions, hence the twenty-seven such solutions are used in the present study which are supposed to be reliable.

In addition, there are several investigators who have contributed significantly to understand the seismotectonics and the related stress pattern in Himalaya and Tibet regions (for example Fitch, 1970; Tandon and Srivastava, 1975; Molnar et al., 1977; Gupta and Singh, 1980; Dasgupta et al., 1987; Verma and Kumar, 1987; Verma and Reddy, 1988; Rajendran et al. 1992; Singh and Shanker, 1993; Singh, 2000; Ghimire and Kasahara, 2007; Paudyal, 2011). Using long period records of WWSSN, Gupta and Singh (1980) determined the fault-plane solutions of the Nepal Himalaya and inferred the thrust faulting, in general, with a few cases having a small component of strike-slip faulting. Thrust faulting and the crustal shortening along the normal to the southern margin of the Tibetan plateau were derived through fault-plane solutions by Molnar and Lyon-Caen (1989). Shanker et al. (2002) have also indicated a regional large scale normal faulting pattern in Tibet and the thrust dominated faulting in the Himalaya using stress simulation analysis. Besides using P-wave first motion directions, the waveforms of body and surface waves have also been used by some scientists to obtain improved fault-plane solutions. Most of the results of fault-plane solutions show normal faulting with east-west tension for the earthquakes located near to and to the north of the Indus suture, whereas the fault-plane solutions for the earthquakes occurring between the MBT and the MCT or slightly north of the MCT have thrust solutions, with nodal planes dipping gently towards the north. Two earthquakes in the Ganga basin showed normal fault-plane solutions. These studies were carried out on regional scale with a limited number of fault-plane solutions. However, such studies were not extended to a local scale for a region like Nepal using larger number of fault-plane solution data.

In this paper, we have tried to infer the recent trend in the faulting pattern taking place in the Nepal Himalaya and its adjoining region using the new and the existing fault-plane solutions of eighty-three events that occurred in the last forty years including 1934 great earthquake along with earthquake occurrence patterns for study the impending earthquake hazard. Using these fault-plane solutions, it is studied here the faulting pattern in relation to the major tectonic features, the nature of faulting in the vertical sec- 
tions along east-west and north-south directions and the prevailing stress condition using the orientation of pressure and tension axes. Such investigations helped in extracting the additional information which, in turn, improved the current understanding of the seismotectonics of the Nepal and its adjoining region.

\section{Geology of the Region}

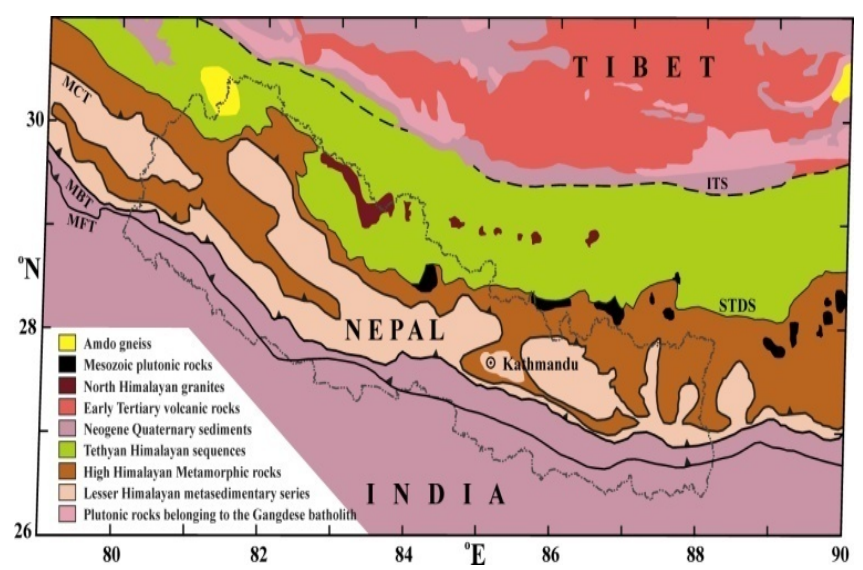

Figure 2.1. Geology of the Nepal and its adjoining region, Central Himalaya (after Yin and Harrison, 2000). MFT- Main Frontal Thrust, MBTMain Boundary Thrust, MCT- Main Central Thrust, STDS-South Tibetan Detachment System, ITS- Indus Tsangpo Suture

For geological considerations the Indian sub-continent can be divided into three major units: The Peninsular Shield, The Indo-Gangetic Basin and The Himalayas. Other than the foremost two, geology of Himalaya is very complicated due to structural complexity of the rocks and discontinuous nature of most of the lithounits. The Himalayan region is divided into four major morphotectonic zones which are characterized by different physiography and stratigraphy (Heim and Gansser, 1939). From south to north, these are the sub-Himalaya, the Lesser Himalaya, the Greater Himalaya and the Tibetan Himalaya. A number of geoscientists have carried out geological as well as tectonic investigation in the Himalaya and its adjoining regions and published their important findings (Auden, 1935; Gansser, 1964; Le Fort, 1975; Valdiya, 1976, 1981, 1988; Wadia, 1975; Molnar and Tapponnier, 1977; Stockline, 1980; Krishnan, 1982; Dewey et al., 1988; Sharma, 1990; Verma, 1991). A series of reviews focusing on geology and the structural framework have been presented recently: Upreti (1999) for Nepal Himalaya; Avouac (2003) for Central Himalaya; Hodges (2000) and Yin (2006) for the entire Himalayan region, Prasad et al., (2011) for underthrust Indian crust of NW India through multi-fold seismic reflection profile in the Sub-Himalaya, and Yadav et al (2010) for Hindu-Kush-Pamir Himalaya. A simplified geological map of the study region has been presented in Fig. 2.1. On the basis of lithology, the tectonic structures and the geological history, Nepal can be divided into five major geologic zones: from south to north as (i) Terai zone (foreland basin); (ii) the Siwalik zone; (iii) the Lesser Himalayan zone; (iv) the Higher Himalayan zone; and (v) the Tibetan Tethys zone (Upreti, 1999). The deposited sediments comprising the Himalaya were part of India's northern continental margin (Molnar, 1990).

A typical problem is there with regard to their age and origin. Both, thick and thin skin tectonics, have played important role in tectonic modification of the Himalaya. There are concrete evidences of block faulting and tear faults, too, in Himalayan Foothills (HF) and Lesser Himalayan Belt (LHB). Due to intensive thrusting at various levels, varied lithologies, some as old as Palaeo-proterozoic, have been exposed and the Tertiary sedimentary prism has been acutely disturbed. These thrusts are getting younger successively due South, indicating varied intense episodes of orogeny. The great Himalayan arc extends from Nanga Parbat $(8,138 \mathrm{~m})$ in the west to Namche Barwa $(7,756 \mathrm{~m})$ in the east (Le Fort, 1996). This region, having length about $2400 \mathrm{~km}$ and width of about 200 to $250 \mathrm{~km}$, includes Nepal and some parts of Pakistan, India, China, Bhutan and Bangladesh. The Himalaya, the highest mountain range of the world, represents an active collisional orogeny combining rapid crustal shortening and thickening, and that causes frequent strong earthquakes (Avouac, 2003). The Tibetan Plateau lies to the north of the Himalaya with the Indus-Ganga- Brahmaputra plain to the south of it. The Nepal and its adjoining region lie at the central part of the Himalaya.

A number of plate tectonic models for the evolution of the Himalaya were proposed (Dewey and Bird, 1970; Powell and Conaghan, 1973; Seeber et al., 1981; Ni and Barazanzi, 1984). Deway and Bird (1970) postulated a continent-continent collision model and suggested that the Himalaya was formed solely by the collision of Indian lithospheric plate with the Eurasian continental margin. Powell and Conaghan (1973) proposed two stage model for the origin of the Himalaya. The first stage comprised the convergence of northward moving Indian lithospheric plate with the Tibetan land mass during late Cretaceous and $\mathrm{Pa}-$ laeocene before middle Eocene. The Indus Tsangpo Suture (ITS) is the direct result of this collision. In the second stage, further the crustal fractures were developed within the Indian continent during the late Eocene and Oligocene and underthrusting of the Indian lithosphere along these fractures continued from Miocene to present. The low density continental crust and its large thickness prevented further subduction (Isacks et al., 1968; Mckenzie, 1969) that resulted the crustal shortening and initiated the process of mountain building, and also thickened the Tibetan crust (Le Fort, 1975). The current tectonic activity in this region is attributed to the continued collision between the Indian and the Eurasian plate (Molnar and Tapponnier, 1977).

The southernmost part of the study region is Indo-Gangetic plain that extends from the valley of the Indus in the west to Assam in the east. It is formed of Pleistocene to Sub recent alluvial deposits of the rivers of Indus-Ganga system (Wadia, 1975). The Ganga basin is filled with Cenozoic sedimentary rock, and the material is derived largely by the erosion of the Himalaya (Molnar, 1990). The 
Faizabad subsurface ridge divides the Ganga basin into two sub basins. A number of faults under the fore-deep extend northward across the Himalaya foothill (Valdiya, 1981). The alluvium, which constitutes sedimentary fill of Ganga fore-deep, is the youngest foreland basin sediments and its thickness increases towards north due to the bending of the Indian lithosphere.

\section{Seismicity}

The Central Himalayan region is broadly divided into four rectangular seismic regions $\mathrm{A}, \mathrm{B}, \mathrm{C}$ and $\mathrm{D}$ based on spatial distribution of events from 1803 to 2006 and its correlation with tectonic features as shown in Fig. 3.1. The delineated regions A, B and C occupy parts of the Central Himalayan arc; whereas region D comprises South Central Tibet. The regions A, B and C occupy the Western Nepal, the Central Nepal and the Eastern Nepal and their surrounding areas respectively.

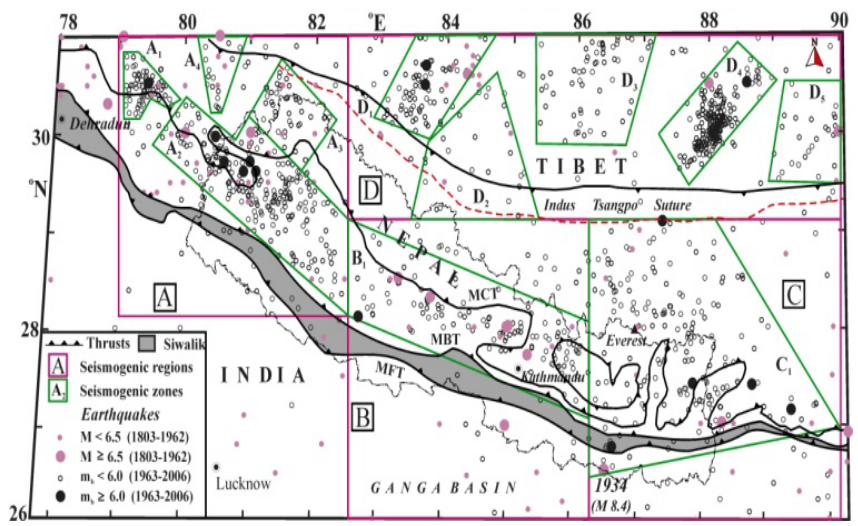

Figure 3.1. Seismicity map (1803-2006) of Nepal and its adjoining region in the Central Himalaya. Main central thrust (MCT), Main boundary thrust (MBT), Main frontal thrust (MFT) and Indus Suture (ITS) are the major tectonic features in the region. The great earthquake of 1934 is located to the south of the MFT. A, B, C and D represent seismic regions that have been delineated based on spatial distribution of distinct seismicity as compared to the surrounding region

Using the same criteria, each region has further been divided into smaller seismic zones which represent intense seismic activity compared to their surrounding areas within the respective region. The region $\mathrm{A}$ is further subdivided into four seismic zones as $A_{1}, A_{2}, A_{3}$ and $A_{4}$; region $B$ into one as $\mathrm{B}_{1}$; region $\mathrm{C}$ into one as $\mathrm{C}_{1}$, and region $\mathrm{D}$ into five zones as $\mathrm{D}_{1}, \mathrm{D}_{2}, \mathrm{D}_{3}, \mathrm{D}_{4}$ and $\mathrm{D}_{5}$ enclosing intense seismic activity (Fig. 3.1). The seismic activity in regions A, B, C and $\mathrm{D}$ are found to be in the ratio $3: 1: 2: 3$, respectively based on the total events from 1963 to 2006; whereas the total energy release is estimated to be in the ratio $12: 1: 6: 4$ for the same period. These data indicate that the Western Nepal remains the most active with concentrated seismic activity followed by the Eastern Nepal in which seismicity is found to be scattered. On the other hand, the South Central Tibet is moderately active with highest earthquakes frequency, and the Central Nepal remained quiet since 1963. Though the Western Nepal region, at present, is character- ized by the intense seismic activity, the Central and the Eastern Nepal regions have been the sites for the several large earthquakes in the past, e.g., the 1934 great earthquake of Bihar-Nepal border region which occurred in the southern part of the Eastern Nepal region.

A non- uniform spatial distribution of earthquakes with certain segments having intense seismic activity in thrust zone of Central Himalaya signifies complex geologic and tectonic setting. The different parts of the major thrusts exhibit different degrees of seismic activity that varies with focal depth. The recent seismic activities are mainly due to the shallow focus events and these are mostly confined between the surface manifestations of the MBT and the MCT in the Himalayan frontal arc and to the north of the ITS in the South Central Tibet. The intermediate earthquakes have occurred mostly in three localities associated with intense shallow focus activity: Western Nepal, north-northeast of Mount Everest, and north of the ITS along $88^{\circ} \mathrm{E}$. The medium size earthquakes $\left(m_{b} \geq 6\right)$ in Himalayan thrusts occur at deeper levels as compared to the similar magnitude earthquakes at shallowest level in the adjoining Tibet region.

The observed sporadic seismic activity confined to certain segments in the Central Himalaya region is presumably of local origin influenced by the local geotectonic environments that differ from one segment to the other. Eventually, it may be stated that the deeper events are caused by the change in the physical properties due to intense geothermal activity and the high heat flow prevailing at different depths coupled with abnormally high crustal thickness. However, the main cause for seismic activities and the other parameters affecting it is due to enduring compression by northward movement of the Indian plate.

The clustering pattern of the shallow and the intermediate events extending beyond $70 \mathrm{~km}$ focal depth in the Western and the Eastern parts of the Central Himalayan thrusts signify a high crustal thickness. It is strange to note that the region lying east of $82.5^{\circ} \mathrm{E}$ longitude along the major thrusts is almost devoid of intermediate earthquakes which may be due to the presence of an aseismic block extending downwards to the lower crust or beyond it. Khattri and Tyagi (1983) identified a seismic gap between the rupture zones of the two great earthquakes of Kangra (1905) and Bihar-Nepal (1934). The further analysis of the seismicity data from 1800 to 1976 shows that there has no such earthquake occurred in the seismic gap region so far. They called this region as the Central Seismic Gap and concluded that this gap has high seismic potential for future activity.

A periodic high and low seismicity phases from 1803 to 2006 in the Central Himalayan region have been observed being coincident with the sites of several large earthquakes of $M \geq 7$. In order to understand the space-time relationships of large events, the epicenters of such events were projected onto the arc XY (Fig. 3.2) which corresponds to the Himalayan frontal arc. In the figure, the distance along $\mathrm{XY}$ is measured from point $\mathrm{X}\left(30^{\circ} \mathrm{N}, 79^{\circ} \mathrm{E}\right)$ to the projected position of epicenter is used as a single space coordinate to 
describe the earthquake. Using the above defined spatial coordinates and the time of occurrence of earthquakes, a two dimensional space-time plot of earthquakes for $M \geq 6$ was prepared as shown in Fig. 3.2.

The Central Himalayan thrusts are the result of continent- continent collision of two mega plates of India and the Eurasia. In this region, the seismic energy is built up due to incessant collision of Indian plate with the Eurasian plate which results in a sudden release of the stored seismic energy in large and great earthquakes. In order to understand the energy release pattern in the region for the period 1963 to 2006, the annual and the depth wise seismic energy release has been estimated for all the four delineated regions, namely $\mathrm{A}, \mathrm{B}, \mathrm{C}$ and $\mathrm{D}$ using the formula established by Bath (1973) for the body wave magnitude.

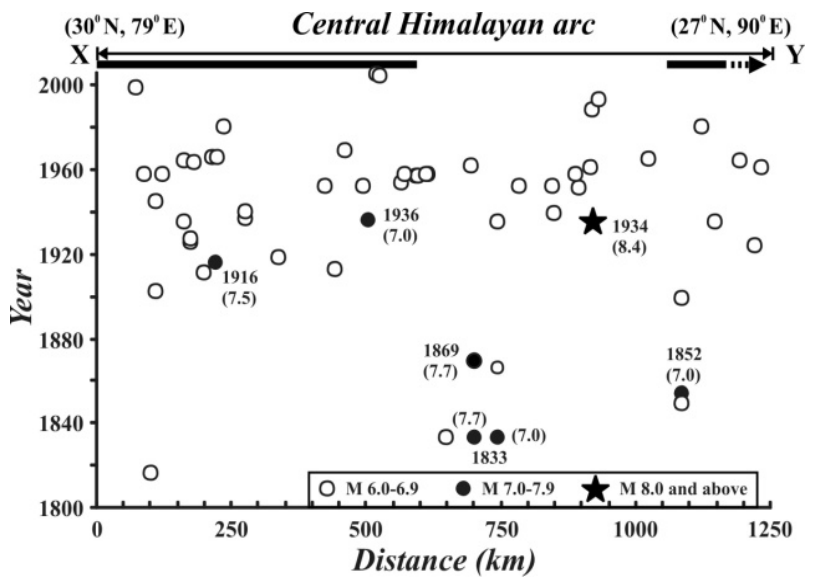

Figure 3.2. Space-time plot of large earthquakes $(M \geq 6)$ in Central Himalayan region (1803-2006), the projected position of the epicenters on the profile X-Y represents Himalayan arc. Black horizontal bars shown below XY line are the probable extent of identified seismic gap susceptible for potential slip in future great earthquake. Black bar with arrow pointing towards east indicate its possible extension
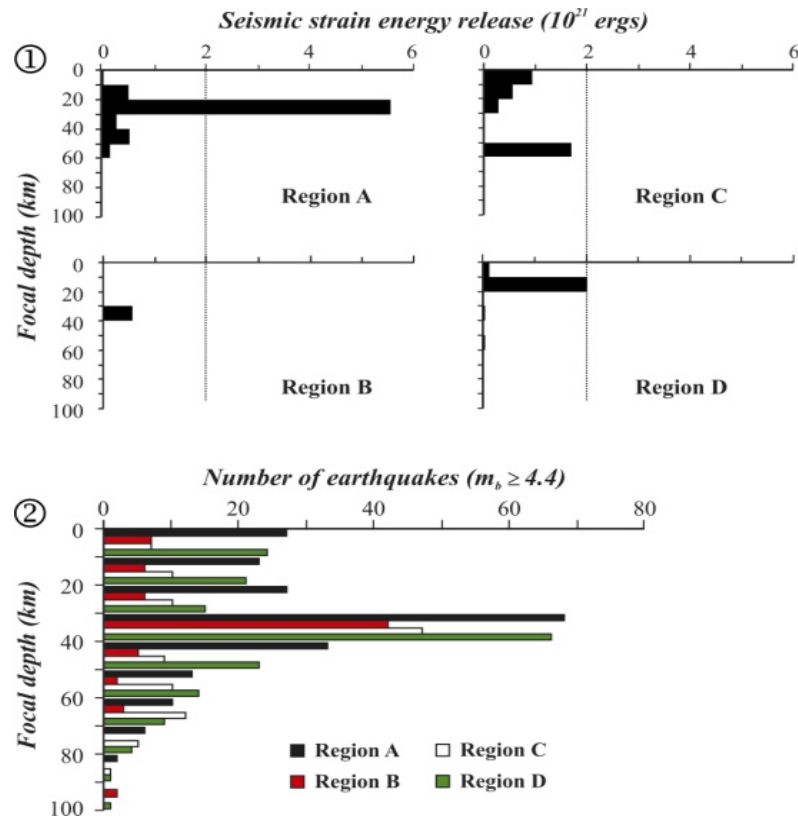

Figure 3.3. Seismic energy release with depth (1) and relation between the number of earthquakes and focal depth (2) in regions A, B, C and D for the period 1963-2006

\section{Focal Mechanism Solutions}

The majority of these events in this part of Himalayan thrust belt are shallow (13-37 km) with five events with the focal depth $43-56 \mathrm{~km}$.

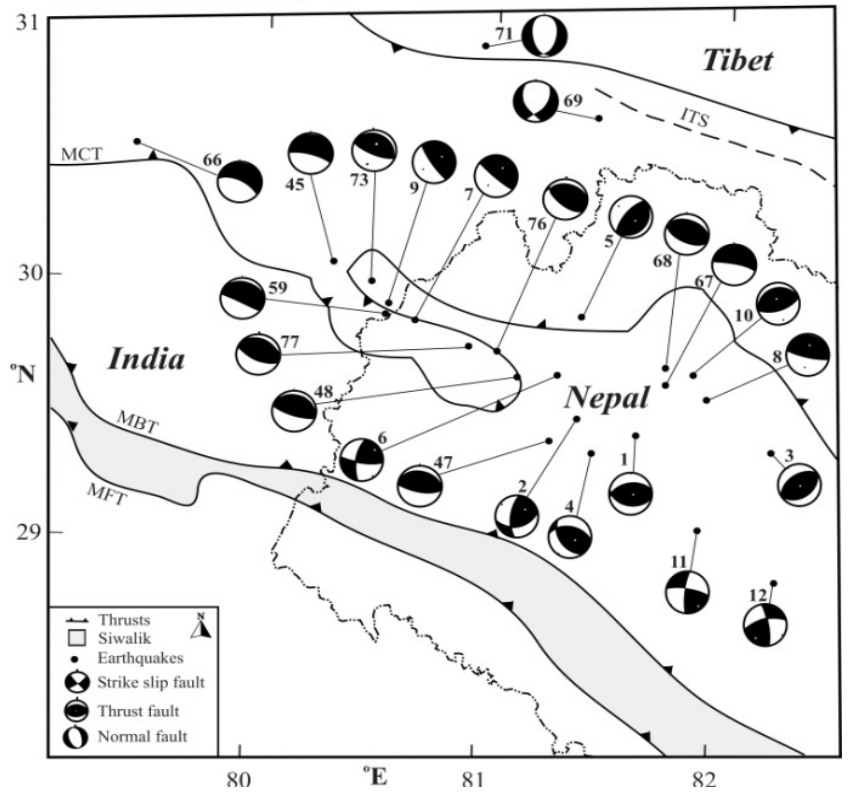

Figure 4.1.1. Nature of faulting patterns in Western Nepal and its adjoining region. Epicenters of the earthquakes are shown by solid circle. Shaded quadrants represent compressional first motion, and opens are dilatations. The numbers attached to each solution is their respective serial. It may be noted that almost all of the solutions show thrust faulting along the Himalayan belt with a few having strike-slip nature with large thrust components. Two earthquakes located near the ITS show normal faulting with east-west extension

\subsection{Western Nepal and its adjoining region (Region $A)$}

The beach balls of fault-plane solutions of twenty-four earthquakes, including twelve new solutions are depicted in Fig. 1. Most of the solutions exhibit thrust faulting with nodal planes dipping towards north or north-east and a few towards northwest. Ten fault-plane solutions corresponding to events $1,4,8,45,47,48,59,66,67$ and 76 (Fig. 4.1.1) are found to exhibit thrust type mechanism with north dipping nodal planes; whereas the solutions 3, 5 and 10 have northwest dip. The nodal planes related to the events 7,9 , 68, 73 and 77 dip towards north-east. The inferred motions through these solutions indicate northward underthrusting of Indian plate along the major thrusts of the Himalaya. The three solutions to the events 6,11 and 12 which are located north of the MBT show strike-slip mechanism with a small thrust component. However, the event 2, also located in the same locality, has similar mechanism with a large thrust component. The motion along the nodal planes of events 2 , 6 and 12 are of sinistral type, whereas the event 11 is associated with a dextral type motion. The inferred fault planes of these four events show their association with the transverse faults which are trending NE-SW. Two shallow events $(\sim 10 \mathrm{~km})$, solutions 69 and 71, are located close to the ITS in the Tibet region show normal faulting with the north-south oriented nodal planes having east-west exten- 
sion. Four moderate size earthquakes with $m_{b} \geq 6$ (solutions 48, 66, 73 and 76), including Chamoli and Bajhang earthquakes, are located within $150 \mathrm{~km}$ along the Himalayan major thrusts. These earthquakes show similar thrust mechanism with shallow angled north dipping nodal planes agreeing with the general trend of the major thrusts. The faulting pattern as inferred here is in general agreement with the structural features (the major thrusts and the transverse faults) are present in the region. Though the nodal plane of the individual event differs slightly in their orientation, but the collective dips indicate northward movement at shallow angle.

\subsection{Central Nepal and its Adjoining Region (Region B)}

The fault-plane solutions for the ten events located in the Central Nepal and its adjoining region occurred from 1965 to 2004 were determined in the present study to infer ongoing geodynamic processes in the region. The beach balls of the fault-plane solutions of fourteen earthquakes, including ten new solutions are depicted in Fig. 4.2.1. Thus it confirms that there is an underthrusting of the Indian plate towards north at shallow angle in the central part of the Nepal Himalaya.

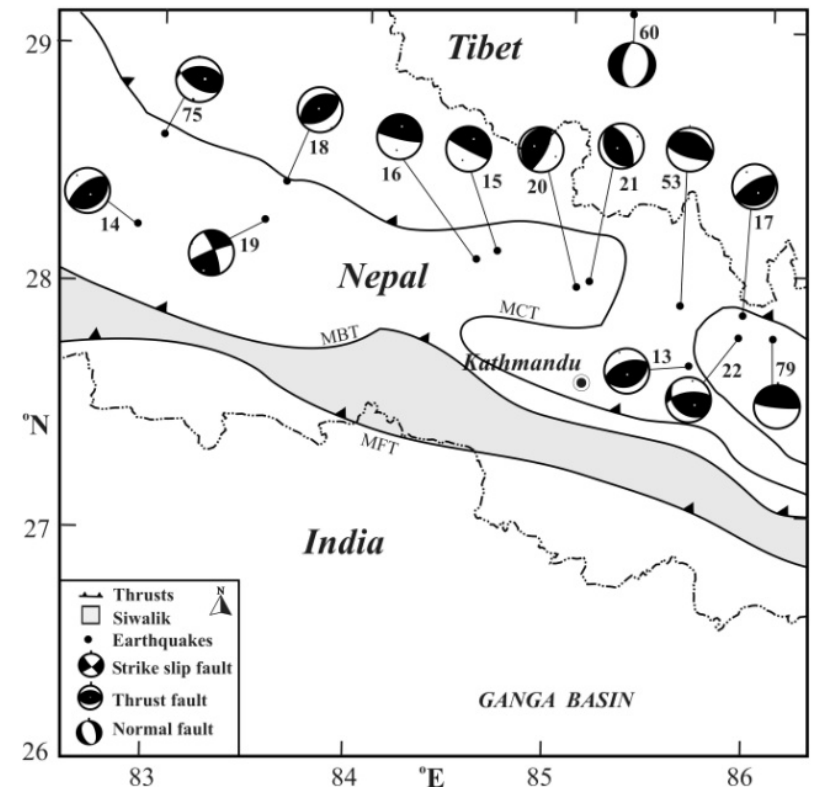

Figure 4.2.1. Fig. 4.2.1. Nature of faulting patterns in Central Nepal and its adjoining region Epicenters of the earthquakes are shown by solid circle. Shaded quadrants represent compressional first motion, and opens are dilatations

\subsection{Eastern Nepal and its Adjoining Region (Region C)}

The seismic activity in the Eastern Nepal region is considerably high and offsets towards north extending up to the ITS in which shallow and intermediate focus earthquakes occur frequently. Shallow events are mostly confined to major thrusts and transverse faults; and the activity in the adjoining Tibet region lie close to north-south trending normal faults/ graben structures. The fault-plane solutions, for events occurred in this show strike-slip motion with large thrust component and a few with thrust and normal faulting characteristics (Paudyal et al., 2008). The majority of events considered in the present analysis to infer faulting pattern in Eastern Nepal Himalaya and its vicinity are shallow focus within $35 \mathrm{~km}$, three earthquakes (events 26, 52 and 83) between $54-57 \mathrm{~km}$ and an isolated earthquake (event 28) at intermediate depth of $79 \mathrm{~km}$.

The 1988 Udaypur earthquake (event 52) has occurred in the vicinity of rupture zone of the great earthquake of 1934 (event 72) and both show similar faulting pattern with combination of thrust and strike-slip motion. The fault plane of 1934 earthquake (strike $280^{\circ}$, dip $30^{\circ}$ and slip angle $40^{\circ}$ ) shows underthrusting towards southwest. Pandey and Nicolas (1991) reported thrust faulting with right lateral strike-slip component for the 1988 Udaypur earthquake and the inferred fault plane (WNW-ESE) is compatible with general trend of major tectonic features. Another large earthquake (event $82 ; \mathrm{mb} 6.1$ ) located near the MCT around Darjeeling revealed predominantly strike-slip faulting pattern (Ni and Barazangi, 1984). They reported north-south trending P-axis and east-west trending T-axis for this event which is consistent with strike-slip and reverse motion along the existing fault in the Lesser Himalaya.

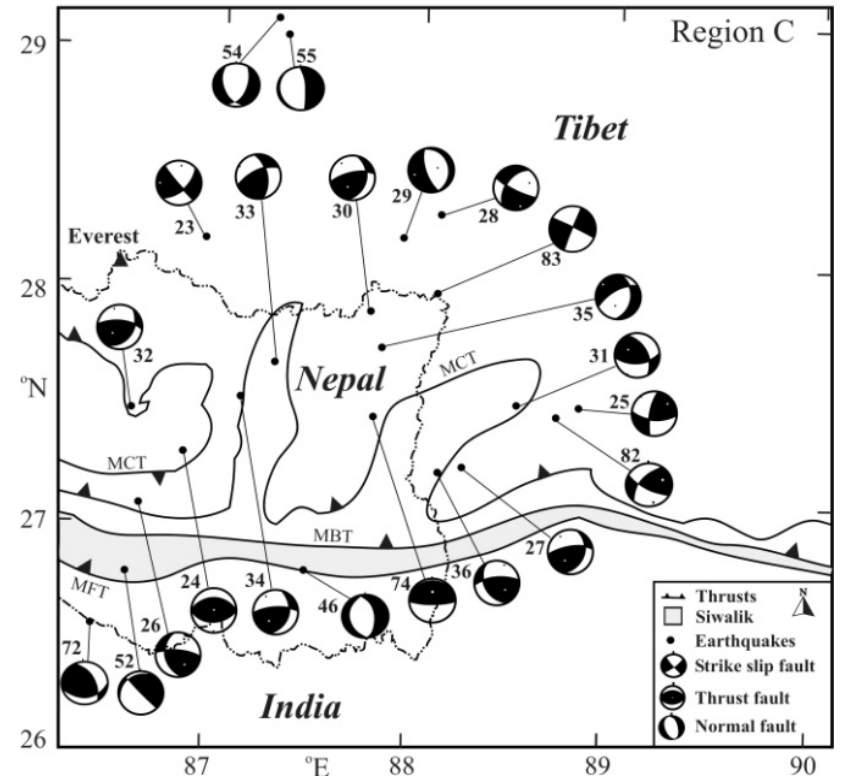

Figure 4.3.1. Fault-plane solutions in Eastern Nepal and its adjoining region. Epicenters of the earthquakes are shown by solid circle. Shaded quadrants represent compressional first motion, and opens are dilatations. 3.4.1. Figure Captions

\subsection{South Central Tibet (Region D)}

There has been considerable increase in the seismic activity in the South Central Tibet during the last three decades. The activity is diffused and reported to be associated with normal faults/ graben structures (Molnar and Chen, 1983) and geothermal energy sources (Si-Yu and Xiao-Yue, 1989). The fault-plane solutions for eight earthquakes (events 37-44) of this region which occurred from 1971-1996 were determined in the present study. The Fig. 3.11 shows the details of the newly determined fault-plane solutions. The magnitudes of these events range from 
$\mathrm{m}_{\mathrm{b}}$ 4.8-5.4 with focal depths range from 15 to $35 \mathrm{~km}$, but one event shows a depth of $6 \mathrm{~km}$. Most of these solutions are characterized by normal faulting with roughly north-south striking nodal planes. The schematic orientation of nodal planes of fault-plane solutions of twenty-three earthquakes considered in the present study (are depicted in Fig. 4.4.1

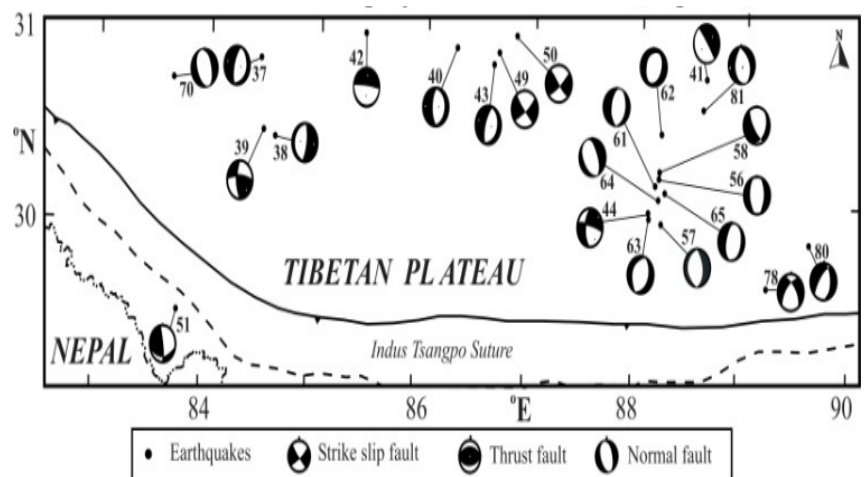

Figure 4.4.1. Fig. 4.4.1. Fault-plane solutions in the South Central Tibet region. Solution numbers 37 to 44 are determined in the present study and rests are compiled from the literatures. Epicenters of the earthquakes are shown by solid circle. Shaded quadrants represent compressional first motion, and opens are dilatations

In the South Central Tibet region, the stress field is observed to be totally different than that of the Central Himalaya. In the South Central Tibet region, the tension axes are mostly horizontal and pressure axes are mostly vertical which represent the east-west flow of the materials perpendicular to the north-south striking nodal planes.

From the orientation of the minimum compressive stress, it may be stated that the earthquake generation process in Tibet is entirely different than that of the Himalaya. The minimum compressive stress is horizontal in the Tibet region representing earthquake process is due to the flow of materials in east-west direction. A concentrated pattern of steeply dipping tension axes shows that there is no mass movement in the Nepal Himalaya region contrary to that of Tibet. The faulting pattern in the adjoining Tibet is totally different than Himalayan compressed belt where normal faulting is predominant with north-south trending nodal planes leading to east-west flow of materials. The data furnished in Table 1 also suggest that most predominant mode of energy release in the Nepal Himalaya region is due to thrust faulting, whereas mechanism for energy release is normal faulting in the South Central Tibet.

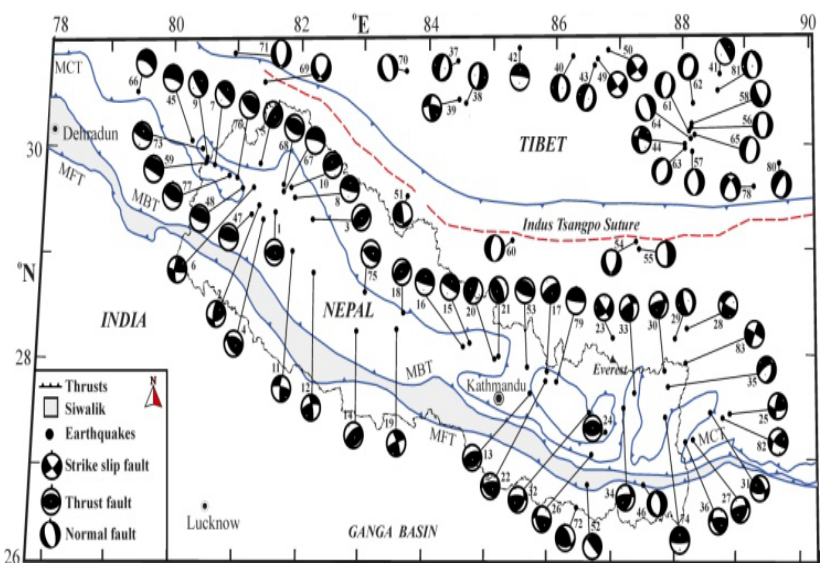

Figure 4.4.2. Nature of faulting pattern in the Nepal Himalaya and its adjoining region. Epicenters of the earthquakes are shown by solid circles. Shaded quadrants represent compressional first motion, and opens are dilatations. It is evident that the Central Himalayan region is dominated by thrust environment whereas the adjoining South Central Tibet by normal faulting showing an extensional zone

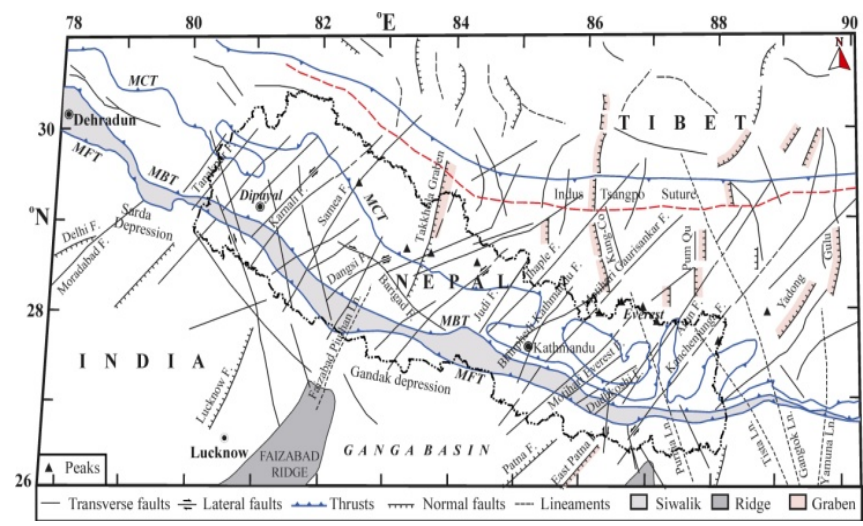

Figure 5.1. A simplified tectonic map of the Central Himalaya and its adjoining region showing major faults (after Dasgupta et al., 1987)

Table 4.1. Frequency of different types of fault-plane solutions observed in four delineated seismogenic regions in the Nepal Himalaya and its vicinity. Please note that the numbers shown within parentheses under normal column (6th column) are the earthquakes actually located in the Tibetan part, north of the Himalayan thrust belt though they are falling in the delineated regions A, B, and C. This statistics are established considering 83 fault-plane solutions

\begin{tabular}{|c|c|c|c|c|c|c|}
\hline \multirow{2}{*}{ Seismogenic Regions } & \multirow{2}{*}{$\begin{array}{l}\text { Nunber of } \\
\text { fault-plane } \\
\text { solutions }\end{array}$} & \multicolumn{5}{|c|}{ Frequency of different types of fault-plane solutions } \\
\hline & & Thrusts & Strike-slip+Thrusts & Strike-slips & Normal & Strike-slip+ Normal \\
\hline $\begin{array}{l}\text { Western Nepal } \\
\text { (Region A) }\end{array}$ & 24 & 18 & 4 & -- & (2) & - \\
\hline $\begin{array}{c}\text { Central Nepal } \\
\text { (Region B) }\end{array}$ & 14 & 11 & 1 & 1 & (1) & - \\
\hline $\begin{array}{l}\text { Eastern Nepal } \\
\text { (Region C) }\end{array}$ & 22 & 2 & 14 & 1 & $1(3)$ & 1 \\
\hline $\begin{array}{l}\text { South Central Tibet } \\
\text { (Region D) }\end{array}$ & 23 & -- & 1 & 2 & 17 & 3 \\
\hline Total solutions & 83 & 31 & 20 & 4 & 24 & 4 \\
\hline
\end{tabular}




\section{Tectonics}

The collision and the resulting continuous subduction of the Indian continental lithosphere experiencing resistance from the Eurasian landmass from the northern side was the main cause of the compression on the region, which produced several major thrusts. The ITS is the direct result of this collision and represents the boundary between these two mega plates. The main tectonic features of Himalayas are the MCT, the MBT and the MFT which developed from north to south in decreasing ages; and these thrusts control the fundamental tectonic framework of the Himalaya. All of these major thrusts extend all along the Himalayan range and are nearly parallel to each other and merge at Moho (Le Fort, 1975, 1994; Molnar and Lyon Cean, 1988; Molnar, 1990), or in a common mid-crustal decollement known as Main Himalayan Thrust (MHT) (Schelling and Arita, 1991). These thrusts divide the region into different tectonic provinces. A simplified tectonic map showing faults and major lineaments is given in Fig 5.1.

The MCT, the first thrust to break Indian plate was developed around 24 to $25 \mathrm{Ma}$ ago and is situated about 250 $\mathrm{km}$ south of the ITS. The MCT extends for nearly $2400 \mathrm{~km}$ along the strike and forms the early Indian-Asian plate convergence zone. Heim and Gansser (1939) first defined the MCT as the thrust placing the Higher Himalayan sequence over the Lesser Himalaya meta-sedimentary strata. Later, Le Fort (1975 argued that the MCT is a fault within lesser Himalayan rocks. The MCT separates two fundamentally different zones of the Himalaya: the Lesser Himalaya and the Higher Himalaya. The MCT in Nepal region is associated with several active fault systems such as: the NWN-SES trending Darma fault $(\sim 15 \mathrm{~km}$ long); the NW-SE trending Talphi fault $(\sim 10 \mathrm{~km}$ long $)$; the WNW-ESE trending Tibrikot fault ( $20 \mathrm{~km} \mathrm{long})$; and a NW-SE trending fault in Dhaulagiri region $(\sim 20 \mathrm{~km}$ long) (Nakata, 1982). Similarly, the active faults in the MCT and the Lesser Himalaya trends in NW-WNW to ESE being oblique to the Himalaya belt. A few right lateral strike slip faults have north-south orientation that extends from Tibetan plateau to Nepal. In the Western Nepal, Dharma Fault, Thakkhola and NW-SE trending Bari-Gad fault ( $\sim 150 \mathrm{~km}$ long) are observed to be important from tectonic points of view (Jouanne et. al, 1999).

The MBT lies nearly $50 \mathrm{~km}$ south of the MCT and it separates the meta-sedimentary rocks of the Pre-Tertiary Lesser Himalaya from the conglomerates and the sandstones of the Sub Himalayan belt (Siwalik formation). It is a continuous structure throughout the Himalayan range having offset at many places by nearly north-south transverse faults, and is presently partly active (Nakata, 1989). South-west directed movement is associated with the MBT, and it was developed since Pliocene time. The MBT has been active through the Pleistocene (Le Fort, 1975, Valdiya, 1981). The active faults in the MBT have east-west as well as NW-SE trend. The active faults include nearly $80 \mathrm{~km}$ long Rangun Khola fault between rivers Kali and Karnali in
Far Western Nepal; about 120 km long Surkhet- Ghorahi fault between Surkhet and Ghorahi; almost $60 \mathrm{~km}$ long Arun khola fault to the north of Butwal city in Dobhan Khola; east- west running nearly $40 \mathrm{~km}$ long Hetauda fault along Churia and Bagmati rivers; about $85 \mathrm{~km}$ long WNN-ESS trending Udayapur fault in eastern region; and Saptakosi - Mechi fault that runs from Dharan to Mechi (Nakata, 1982, 1989).

The southernmost thrust of the Himalaya is known as the MFT that separates the Siwalik rocks from the Gangetic alluvium which consists of shale, thick bedded sandstones, conglomerates, etc. Tectonically, although Siwalik group rocks are faulted, folded and thrusted to the south over Terai region, this region is less complicated than the overlying lesser Himalayan zone. The active faults in the MFT system are the Sangur Khola fault trending NW-SE in the west of Bajura district; the Jumla fault having NW-SE trends for $5 \mathrm{~km}$ in the east of Jumla town, about $140 \mathrm{~km}$ long Bari Gad fault with trending NW-SE, nearly $17 \mathrm{~km}$ long the Dhorpatan fault to NNW-SSE, the Jhimruk Khola fault along the lower course of Jhimruk khola trends WNW-ESE and is about $15 \mathrm{~km}$ long. Similarly ENE-WSW trending Kalphu Khola fault in the north west of Kathmandu, $10 \mathrm{~km}$ long Kulekhani fault trends NNW-SSE along the course of Kulekhani river, $7 \mathrm{~km}$ long NW-SW trending Sunkoshi- Rosi fault which is parallel to the Sunkoshi and Rosi river are known (Nakata, 1989; Sharma, 1990).

Many transverse lineaments are present between the Gangetic fore-deep and the ITS across the Himalaya. Strikes of these transverse lineaments, in general, vary from northwest to northeast, and are parallel to the outline of the sub-surface ridges underlying the fore-deep (Dasgupta et al., 1987). They are, the Faizabad-Piuthan; Motihari- Gaurishanker; Motihari-Everest; Arun; Kanchendzonga; Purnia-Everest; Tista; and Gangtok lineaments. A few of them are reported to be seismically active.

\section{Precursor and Earthquake Forecasting}

Changes in seismicity pattern both in space and time are the most common precursory indicator which plays a significant role in identifying the anomalous seismicity preceding the medium to large size earthquakes. The sequence of events, constituting anomalous seismicity, fluctuates in the order as low-high-low pattern prior to the mainshocks. The spatio-temporal distribution pattern of seismic activity plays an important role in understanding the future seismic hazards of a region. A gradual increase or a decrease in seismic activity in a region has been considered as an important parameter which is some way or other related to the occurrence of forthcoming earthquake. Prediction of earthquakes related hazards is usually undertaken on observing certain premonitory phenomena, known as precursors, developed at different stages in the pending focal region of an 
earthquake. The changes in seismicity rate have been the most promising means of recognizing the possible seismic pattern. The existence of an anomalous seismic activity is generally observed prior to the earthquakes in different seismic belts that precede well in advance as compared to the other precursory phenomena (Sekiya, 1977). The time and place of forthcoming mainshock may be estimated by employing the characteristics of precursor observed in a region. On the basis of time scale, earthquake precursors may be classified in three categories as: long term, intermediate term and short term precursors. The long and intermediate term precursors reflect the seismic hazard of a region in the coming few years and they are important as they occur well in advance of the mainshock. They provide opportunity to search for short-term precursors and help in narrowing down the space and time windows for the impending earthquake. The short term precursors appear before a few weeks of the occurrence of the mainshock which forms an invaluable parameter for earthquake prediction.

Earthquake swarms sequences of earthquakes without a clear main event- have been recorded all over the world. The most prominent feature commonly noticed is precursory activation of seismic belts which include the focal regions of main shocks. The majority sequences, irrespective of the largest event in the sequence and the duration of the sequence, have swarm characteristics that are, the difference in magnitude between the largest and second largest event is 0.3 magnitude units or less. Generally, smaller sequences characteristically have interval of a few hours to a day in length, whereas sequences with large magnitude events may continue for several weeks. In 1977 Frank Evison identified the first examples of earthquake swarms as long-term precursors of main-shock events, and thereby discovered the predictive scaling relations of long-term seismogenesis (Rhoades, 2010). From a study of earthquake sequences Evison (1977) found that in New Zealand and California a single swarm is precursory to a single mainshock event. The time interval between the onset of the swarm and the occurrence of the mainshock is found to be dependent on the magnitude of the mainshock. Evison (1982) observed that in a particular region a swarm may be followed by other swarms. This is an indication that a possibly wider area will be placed at risk and revised estimates for magnitude and time of occurrence of the main shock may be necessary. Several authors (Bufe et al., 1977; Gupta and Singh, 1989; Shanker et al. 2010; Singh et al. 2010) have reported changes in seismicity patterns before the occurrence of medium to large earthquakes. Gupta and Singh (1986) observed that it is important to recognise swarm and quiescence before the occurrence of the main shock and made successful prediction of 06 August, 1988 Indo-Burma border earthquake. In terms of analysis for the space-time distribution of earthquakes sequences with precursory swarm characteristics have been applied in South Central Tibet of the northern Himalayan region for predicting the potential location of future earthquake.

\subsection{Estimate of Future Earthquakes}

The earthquake data compiled for the period 1963-2006 has been used for the identification of seismicity patterns in the Nepal Himalaya region and to make them use in the possible earthquake forecasts in the considered region and vicinity.

\subsection{Western Nepal Himalaya and its Adjoining Region}

Two anomalous seismic activity/ swarm sequences in the Western Nepal region are observed which occurred during (i) 15 Apr. 2001-04 June 2002 and (ii) 25 Oct.-12 Dec. 2005 with as 5.6 and 5.0, respectively (Table 6.2.1) for which no mainshock occurred till 2007 and the gap episodes still continues. Here, it is estimated that the magnitude of the expected earthquake M 6.6 and $\mathrm{Tp} 6.7$ years for the case (i) and M 6.0 and Tp 3 years for the case (ii) using corresponding values in the predictive equations established (Singh et al., 2010) for the Himalayan Frontal Arc. According to the first estimates, the expected earthquake with M 6.6 should have occurred by the end of 2007 but no such activity has been observed so far. On considering the second estimates, an earthquake with M 6 should occur by September 2008 in the same region. The anomalous activities associated with these two cases have occurred in the same locality and a large portion of their delineated preparatory areas are common but with different orientations. The events occurred during 25 Oct.-12 Dec. 2005 within the gap episode of case (i) constitutes the anomalous activity for the case (ii). Evidently, this is the case of a repeated swarm sequence as pointed out by Evison (1982) in which the second activity has occurred in the gap episode of the first case which was continuing. In view of the above, it may be considered that these two cases have probably a common origin and represents some kind of causative inter-relationships. The occurrence of the repeated swarm sequence may indicate that a wider area is under threat which requires re-estimates of the magnitude and the time of occurrence of the impending earthquake (Evison, 1982) after applying the required corrections. Such situation may also change the rate of stress accumulation in the pending focal region (Singh and Singh, 1984) which is evidently increases the duration of the preparatory period and the magnitude associated with impending earthquake. Now, it is thought here that the delay in the occurrence of an expected earthquake is probably due to the interruption in the continuing gap episode of the first sequence by the second one that has enhanced both the preparatory period and the magnitude. In view of the above and the inherent level of error in the magnitude estimation, the magnitude of the impending earthquake may be M 6.50 .5 . In this condition, a precursory time period of 10.7 years for an earthquake with M 7 is estimated using the predictive equation (Singh et al., 2010). If so, the expected earthquake should occur at any time from now onwards till December 2011. If not, then reassessment of the area with new recent data must be analysed. Gupta and Singh (1986) have also made similar 
consideration to estimate the probable time of occurrence of 06 Aug. 1988 in Arakan Yoma.

The same region of the Western Nepal was also considered as one of the seismogenic sources in which probability is estimated to be as $85 \%$ for the next 10 years from 2005 for an earthquake with magnitude 6.40 .2 using the time and magnitude predictable model (Paudyal et al., 2009). It is worth to mention that the estimates of time and magnitude associated with the impending earthquake using two different methods, namely the anomalous seismic activity and the time-magnitude predictable model are in good agreement with each other. The above estimates indicate that the Western Nepal is a potential zone for a forthcoming shallow focus large earthquake. The impending earthquake may lie within the delineated preparatory area bounded by $29.3^{\circ}-30.5^{\circ} \mathrm{N}$ and $81.2^{\circ}-81.9^{\circ} \mathrm{E}$ and its focus would be within $10-30 \mathrm{~km}$ depth. The anomalously low precursory quiescence period is still continuing, and hence this observation may be used to search for other premonitory phenomena, if any.

\subsection{South Central Tibet Region}

In the South Central Tibet region, two anomalously high seismicity phases having analogous spatial and temporal characteristics, separated by about 1.3 years duration occurred during January 2002-February 2003 and June-August 2004 and were concentrated towards south-southwest of the preparatory areas of 1996 and 1998 mainshocks. These two are repeated swarm cases and analogous to that of 2001 and 2005 cases observed in the Western Nepal region. Interestingly in both these cases, no mainshock has occurred till 2007. Under this circumstance, a wider area may be suspected to be under threat if a swarm sequence follows another one as reported by Evison (1982), and it is thought here that the present case is of similar nature. The characteristics of the anomalous seismicity/ earthquake swarms observed in the South Central Tibet region were totally different in many respects than the cases similar to those in the Himalayan compression zone. Due to this reason, the predictive regressions as established here for the Himalayan Frontal Arc cannot be applied for the estimation of predictive parameters related to the pending earthquakes in the South Central Tibet region. Further, it was not possible to establish such regression for the extensional zone of the South Central Tibet region due to the limited number of observations on anomalous pattern.

In most of the anomalous sequences, the magnitude of mainshocks observed to be 1 to 2 units higher than the magnitude of the largest swarm event (Evison, 1977; Singh et al, 1982; Shanker et al., 1995; Singh et al., 2005). In the cases of the South Central Tibet region, such differences are observed from 1 to 1.4 units. In view of this, the magnitude of the impending earthquake associated with the anomalous activities of 2002 and 2004 in the South Central Tibet may exceed 6 . In both these cases, the spatial and the temporal clustering of swarm events are prominent, and they are confined in a vertical column of 10 to $45 \mathrm{~km}$. Considering these facts, the expected mainshock may lie within the delineated elliptical area $\left(\sim 1.6 \times 10^{3} \mathrm{~km}^{2}\right)$ bounded by $29.6-30.1^{\circ} \mathrm{N}$ and $87.8-88.1^{\circ} \mathrm{E}$ and in the depth range $25-15 \mathrm{~km}$.

The preparatory areas associated with eleven mainshocks and of the expected three mainshocks are collectively depicted in Fig. 6.3.1. In general, the preparatory areas oriented in the direction of the local tectonic features are found to be of different size for similar magnitudes of the mainshocks in the same areas. In the Western Nepal and its vicinity, though all the three mainshocks were located close to the surface trace of the MCT in the northwest-southeast direction, their preparatory areas were oriented in different directions, e.g. NW-SE (1999), NE-SW (1984) and E-W (1980) with the mainshocks located in the northern part of the respective preparatory areas. In the case of the expected mainshocks, a large part of their preparatory areas is found to be common; however, they are oriented in the N-S and NW-SE. The preparatory areas of the mainshocks in the Eastern Nepal and its adjoining region have two prominent orientations in NW-SE and NE-SW. Similarly, in the adjoining south central Tibet, there are two prominent orientations of the preparatory areas mainly in NE-SW and N-S directions. There is a significant variation in the sizes of the preparatory areas in this region being smallest $(\sim 800-1300$ $\mathrm{km}^{2}$ ) for the mainshocks of 1996 and 1998 . The preparatory area of the expected mainshock is observed to be of a comparable size with similar orientation as that of the mainshocks of 1996 and 1998.

Table 6.2.1. Characteristics of anomalous seismic activity/ earthquake swarm observed for three cases during 2001-2005 in Western Nepal (S1. Nos. 1-2) and in the South Central Tibet (Sl. No. 3) region along with approx. preparatory areas for the expected mainshocks

\begin{tabular}{|c|c|c|c|c|c|c|c|}
\hline \multirow{2}{*}{ Sl.Nos } & \multicolumn{5}{|c|}{ Characteristics of anomalous seismic activity/earthquake swarm } & \multirow{2}{*}{$\begin{array}{c}\text { Duration of data } \\
\text { examined }\end{array}$} & \multirow{6}{*}{$\begin{array}{l}\text { Remarks: } \\
\text { Mainshock not } \\
\text { occurred till now } \\
\text { Gap episode is } \\
\text { continuing. }\end{array}$} \\
\hline & Date of onset & Study grid & Preparatory atea $(\mathrm{km} 2)$ & Depth range $(\mathrm{km})$ & $\bar{M}_{p}$ & & \\
\hline 1 & 04.15 .2001 & $\begin{array}{l}28.0^{\circ}-31.0^{\circ} \mathrm{N} \\
79.5^{\circ}-82.2^{\circ} \mathrm{E}\end{array}$ & $3.0 \times 10^{4}$ & $5-35$ & 5.6 & 1999-2006 & \\
\hline 2 & 10.25 .2005 & $\begin{array}{l}28.5^{\circ}-30.7^{\circ} \mathrm{N} \\
80.0^{\circ}-82.3^{\circ} \mathrm{E}\end{array}$ & $1.1 \times 10^{4}$ & $10-50$ & 5.0 & 2003-2006 & \\
\hline $3 \mathrm{a}$ & 01.31 .2002 & $\begin{array}{l}29.6^{\circ}-30.6^{\circ} \mathrm{N} \\
87.7^{\circ}-88.6^{\circ} \mathrm{E}\end{array}$ & $1.6 \times 10^{3}$ & $10-65$ & 5.1 & 1999-2006 & \\
\hline $3 b$ & 06.02 .2004 & $\begin{array}{l}29.6^{\circ}-30.6^{\circ} \mathrm{N} \\
87.7^{\circ}-88.6^{\circ} \mathrm{E}\end{array}$ & $1.6 \times 10^{3}$ & $10-56$ & 4.6 & 1999-2006 & \\
\hline
\end{tabular}




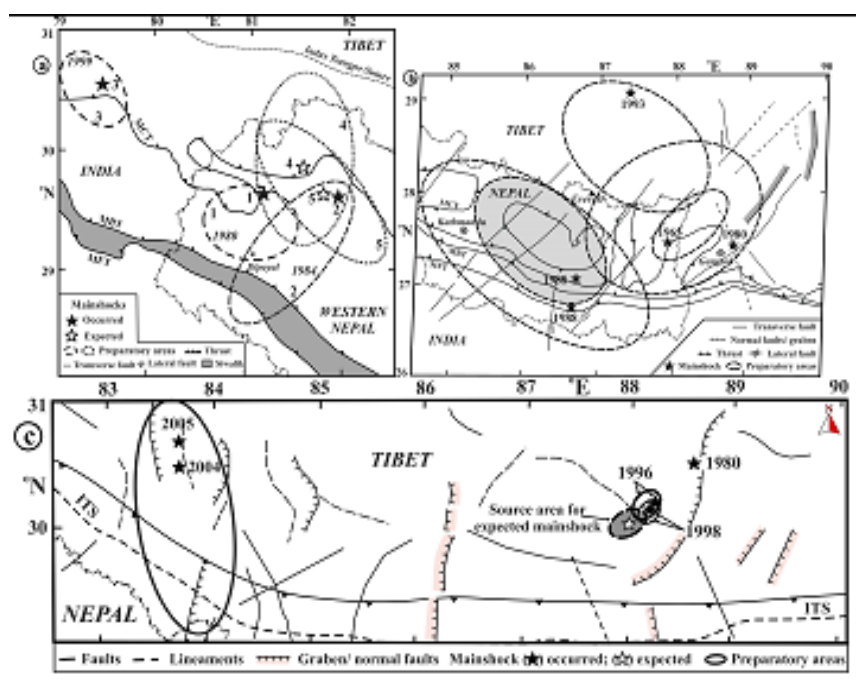

Figure 6.3.1. Orientation of preparatory areas of mainshocks from 1963-2006 that were preceded by anomalous seismic activity in (a) Western Nepal; (b) Eastern Nepal and (c) adjoining Tibet region. Also, probable preparatory areas for expected future mainshocks in Western Nepal and in South Central Tibet region are depicted3.4.1. Figure Captions

Based on the data from 1963 to 2006, the anomalous seismicity/ earthquake swarms prior to the medium size earthquakes in the Nepal Himalaya and its adjoining Tibet region have been studied here. It is established here that the anomalous seismicity/ swarm patterns follow episodes of relatively very low seismic activity and it is an important finding to visualize that an area might be preparing for the occurrence of a forthcoming mainshock. Such anomalous seismic patterns were observed prior to the eleven medium size mainshocks that occurred from 1963 to 2006; seven cases in the Nepal Himalaya and four in its adjoining South Central Tibet region. From these observations it may be inferred here that the patterns of anomalous seismicity/ earthquake swarms may be considered as an important parameter for the forecasting of long-range earthquake hazards in the Nepal Himalaya region. The present study suggests that the parts of the Western Nepal and the adjoining Tibet region are potential for the future medium size earthquakes. Accordingly, it has been estimated here that an earthquake with M 6.5 - 0.5 may occur at any time from now onwards in the Western Nepal within an area bounded by $29.3^{\circ}-30.5^{\circ} \mathrm{N}$ and $81.2^{\circ}-81.9^{\circ} \mathrm{E}$, in the focal depth range $10-30 \mathrm{~km}$. Similarly, an earthquake with a magnitude of about 6 may occur in the South Central Tibet region within an area enclosed by $29.6-30.1^{\circ} \mathrm{N}$ and $87.8-88.1^{\circ} \mathrm{E}$ and in the depth range $25-15 \mathrm{~km}$ at any time from now onwards.

\section{Numerical Modeling}

The occurrence of quaternary thrusting in Himalayas and its geodynamics constraints in southern Tibet is modelled using stress simulation analysis. 2-D non-linear elastic and homogeneous wedge models, representing cross-sections of the Himalayas and Tibet are used (Shanker et al., 2002,
2004). Simulated stresses for a set of boundary conditions, representing building up of Himalayas and southern Tibet, reveals the region of thrust failure gradually recedes away from the wedge towards the base (lower boundary) with a decrease in the strength of the base. Thus, the result favours the preposition that a strong and a weak basal (Main Himalayan Thrust; MHT) respectively, below Himalayas and Southern Tibet is responsible for presence and restricting the extension of Quaternary thrusting in these regions. A decrease in strength of MHT from the Himalayas to Tibet is also supported by observational evidence and thermal modelling, imply partial melting along MHT. Thus, the strength of the Main Himalayan Thrust may play an important role in the mechanical development of Himalayas and Tibet. From the INDEPTH survey, presence of partially molten middle-lower Tibetan crust has been identified. It is proposed that as a result of the understanding of Indian lithosphere underneath Southern Tibet, its attached crust warms and partially melts (Nelson et al 1996, Oldham 1888). Accordingly, as subduction progressed, partial melting is likely to moves from south to north. Hence, exposed crystalline rocks of the Higher Himalayas and Himalayan domes represent progressively younger, frozen, snapshots of partially molten layer presently lying at depth to the north (Nelson et al. 1996). One such dome, the Kangmar dome to the north of the Higher Himalayas, is the surface expression of a basement-cored antiform in the hanging wall of the MHT. This suggests that thrusting did occur before the crust partially melted. A decrease in the strength of the base relative to the wedge interior for case when failure is occurring on entire base inhibits thrusting within the wedge. This view is amenable to simple mechanical explanation. Shanker et al., 2002 concluded that the presence of a weak and a relatively strong MHT below Southern Tibet and Himalayas would have been responsible for the absence and presence of quaternary thrusting respectively, in southern Tibet and Himalayas. Present study of modelling quaternary tectonics using simulated stress distribution verify some of the observational evidences suggesting that the strength of the MHT below Southern Tibet is smaller than below Himalayas.

\section{Result and Discussion}

The nature of stress pattern and their influence on tectonics in the Western Nepal Himalaya region were studied from the composite stereographic projection of orientations of the compression and tension axes of twenty two earthquakes (events 1-12, 45, 47, 48, 59, 66-68, 73, 76 -77; Paudyal et al., 2008, Paudyal, 2011). It is evident that the plunges of P-axis are shallow and almost horizontal; whereas that of the T-axis is almost vertical showing thrust mechanism in this part of the Nepal Himalaya. All of the Pplunges are less than $45^{\circ}$ with around 63 percent lie within $25^{\circ}$ and the remaining lie within $26^{\circ}-42^{\circ}$. On the other hand, over 86 percent of T-plunges are greater than $45^{\circ}$. This ob- 
servation suggests clearly a compressive regime in the Western Nepal Himalaya. It is apparent that the compressive stress is acting in N-S to NE-SW directions which are approximately perpendicular to the major trend of the Himalaya. It also reveals that the earthquake generation process in the region is due to the north-northeast compressive stress exerted by the Indian plate to the Tibetan plate. However, the plunges of $\mathrm{P}$-axis of a few events show compression from approximately northwest direction.

A composite stereographic projection of orientations of the compression and tension axes of thirteen earthquakes, pertaining to the Central Nepal Himalaya, is used to infer the nature of stress direction. The plunges of $\mathrm{P}$-axis are observed to be shallow and almost horizontal; whereas that of the T-axis is almost vertical showing thrust mechanism in the Central Nepal Himalaya. All of the P-plunges are less than $45^{\circ}$ with around 77 percent lie within $28^{\circ}$ and the remaining three lie within $39^{\circ}-42^{\circ}$. Besides, the $\mathrm{T}$ plunges of all the events are greater than $45^{\circ}$ except one earthquake (event 19) which shows the strike-slip motion. This observation suggests that there exists predominantly a compressive regime in the Central Nepal Himalaya similar to that of the Western Nepal Himalaya. It is apparent that the compressive stress is generally acting in NNE-SSW directions which are approximately perpendicular to the major trend of the Himalaya. However, the plunges of P-axis of a few events show compression from approximately northwest direction. From the orientation of maximum compressive stress, it may be concluded that the earthquake generation process in the Central Nepal Himalaya is similar to that of the Western Nepal Himalaya and is due to the under thrusting of Indian plate along the Himalayan major thrusts. The majority of the fault-plane solutions indicate predominantly a compressive environment with gently northward dipping nodal planes in the Central Himalaya region; whereas in the adjoining South Central Tibet region it is mainly the east-west extension with normal faulting. This is due to the compression exerted by the northward movement of the Indian plate. The Indian continental lithosphere appears to be thrusting at a gentle angle. Predominantly thrust faulting exists throughout the Nepal Himalaya showing a compressive stress regime. The inferred direction of compressive stress is acting almost perpendicular to the Himalaya suggesting crustal shortening in north-south direction. In contrary to this, the normal faulting with north-south trending nodal planes is predominant in the South Central Tibet region with an approximately horizontal $\mathrm{T}$-axis indicating east-west flow of the Tibetan landmass. The prevailing regional stress conditions at shallower levels in compression as well as in extension zones extend up to the deeper levels in to the upper mantle as evidenced by the faulting pattern in the region. The observed stress patterns in the South Central Tibetan plateau are quite different from those of the Himalayan front. In the South Central Tibet, tension is predominant; whereas in the Nepal Himalaya region it is compression. From the orientation of the minimum compressive stress, it may be stated that the earthquake generation proc- ess in Tibet is entirely different than that of the Himalaya. The minimum compressive stress is horizontal in the Tibet region representing earthquake process is due to the flow of materials in east-west direction. A concentrated pattern of steeply dipping tension axes shows that there is no mass movement in the Nepal Himalaya region contrary to that of Tibet. Different segments of the Nepal Himalaya and its adjoining region exhibit varying degree of seismicity that is largely influenced by the local tectonic environment. The sole cause for the seismic activity and other parameters affecting it in the region is due to the enduring compression by the northward movement of the Indian plate.

Especially, the study augments the current understanding of seismicity, seismotectonics and stress patterns in the $\mathrm{Ne}$ pal Himalaya and its adjoining Tibet region, which may be extended to other parts of the Himalaya Frontal arc. The patterns of anomalous seismicity may be useful in delineating potential zones for the occurrence of future seismic activity and the related long-term hazard assessment in the region. The methodology developed and applied in this work may be extended to other seismically active segments of the Himalayan belt which may provide ample of information to generate a comprehensive model for the estimation of the occurrence of anomalous seismicity and its impact on the long-term seismic hazards prediction and assessment.

Detailed investigation of seismic activity in $\mathrm{Ne}$ pal-Himalaya and vicinity would lead to a better understanding of focal depth, areal distribution of mechanism of earthquakes and their occurrence patterns. It would also help in resolving the suitability of various models proposed to describe the tectonics of the Nepal-Himalaya. This may further help to geoscientists, engineers, policy makers and planners for technical use in risk reduction.

\section{ACKNOWLEDGEMENTS}

Authors are grateful to Prof. V P Singh and Prof. U S Singh, head of Department of Geophysics, Banaras Hindu University, Varanasi India for their continuous inspiration, support and encouragement at every moment in upgrading and organizing the scientific knowledge. One of the authors (HP) is thankful to UGC, Nepal for fellowship and Tribhuvan University for sabbatical leave. Excellent computational facility provided by Department of Earthquake Engineering is gratefully acknowledged.

\section{REFERENCES}

[1] Armijo, R., Tapponnier, P., Mercier, J. L., and Tong-Lin, H. (1986). Quaternary extension in southern Tibet: field observations and tectonic implications. J. Geophys. Res., 91, 13803-13872.

[2] Auden, J. B. (1935). Transverse in the Himalaya. Records of the Geological Survey of India. 69. 123-167. 
[3] Avouac, J. P. (2003). Mountain Building, erosion, and the seismic cycle in the Nepal Himalaya. Advances in Geophysics, 46, 1-80.

[4] Baranowski, J., Armbruster, J., Seeber, L., and Molnar, P. (1984). Focal depths and fault-plane solutions of earthquakes and active tectonics of the Himalaya. J. Geophys. Res., 89, 6918-6928.

[5] Bath, M. (1973). Introduction to the Seismology. Birkhauser -Verlag, Basel, pp. 395.

[6] Biswas, S. (1989). State of stress and its bearing on tectonics under Tibetan Plateau. Physics of the Earth and Planetary Interiors, 54, 4-9.

[7] Bufe, C.G., Harsh, P.W., and Buford, R.O. (1974). Steady-state seismic slip-a precise recurrence model. Geophys. Res. Lett., 4, 91-94.

[8] Chandra, U. (1978). Seismicity, earthquake mechanism and tectonics along the Himalayan range and vicinity. Physics of the Earth and Planetary Interiors, 16, 109-131.

[9] Chen, W. P., and Molnar, P. (1981) Constraints on the seismic wave velocity structure beneath the Tibetan plateau and their tectonic implications. J. Geophys. Res., 86, 5937-5962.

[10] Chen, W. P., Nabelek, J. L., Fitch, T. J., and Molnar, P. (1981). An Intermediate depth earthquake beneath Tibet: source characteristics of the event of September 14, 1976. J. Geophys. Res., 86, 2863-2876.

[11] Dasgupta, S., Mukhopadhaya, M. and Nandy, D. R. (1987). Active transverse features of the central portion of the Himalaya. Tectonophysics, 136, 255-264.

[12] Deway, J. F. and Bird, J.M. (1970). Mountain belts and the new global tectonics. J. Geophys. Res., 75, 2625-264.

[13] Dewey, J. F., Robert, Shackleton, R. M., Chengfa, C., and Yiyin, S. (1988). The tectonic evolution of the Tibetan plateau. Phil. Trans. R. Soc. Lond., A327, 379-413.

[14] Evison, F.F. (1982). Generalized precursory swarm hypothesis. J. Physics of the Earth, 30, 155-170.

[15] Evison, F.F. (1977a). Fluctuation of seismicity before major earthquakes. Nature, 266, 710-712.

[16] Evison, F.F. (1977 b). The precursory earthquake swarm. Physics of the Earth and Planetary Interiors, 15, 19-23.

[17] Fitch, T.J. (1970). Earthquake mechanism of the Himalayas, Burmese and Andaman regions and continental tectonics in Central Asia. J. Geophys. Res., 75, 2699-2709.

[18] Francheteau, J, Jupart, C., Jie, S. X., Wen-Hua, K., De-Lu, L., Bai, Jia-Chi, B., Hung-Pin, W., and Hsia-Yeu, D. (1984). High heat flow in southern Tibet. Nature, 307, 32-36.

[19] Gansser, A. (1964). Geology of the Himalaya. Wiley Inter-Science, London, pp. 289

[20] Gansser, A. (1980). The Significance of the Himalayan suture zone. Tectonophysics, 62, 37-52.

[21] Ghimire, S., and Kasahara, M. (2007). Source process of the $\mathrm{Ms}=6.6$, Udaypur earthquake of Nepal-India border and its tectonic implication. J. Asian Earth Sciences, 31(2), 128-138., doi: 10:1016/j.jseaes.2007.04.007.
[22] Gupta, H. K., and Singh, D. D. (1980). Spectral analysis of body waves for earthquakes in Nepal Himalaya and its vicinity: Their focal parameters and tectonic implications. Tectonophysics, 62, 53-66.

[23] Gupta, H. K., and Singh, H. N. (1986). Seismicity of northeast India region: Part II: Earthquake swarms precursory to moderate magnitude to great earthquakes. J. Geol. Soc. India, $28,367-406$.

[24] Heim, A. and Gansser, A. (1939). Central Himalaya: Geological observations of the Swiss expedition 1936. Mem. Soc. Helv. Sci. Nat., 73 (1), 1-245.

[25] Herrin, E., Arnold, E. P., Bolt, B. A., Clawson, C. E., Engdahl, E. R., Freedman, H. W., Gordon, D. W., Hales, A. L.,. Lobdell, J. L., Nuttli, O., Romney, C., Taggart, J., and Tucker, W. (1968). Seismological tables for P- phases. Bull. Seismo. Soc. Am., 58, 1193-1241.

[26] Hodges, K. V. (200). Tectonics of the Himalaya and southern Tibet from two perspectives. Geol. Soc. Am. Bull., 112 (3), 324-350.

[27] Isacks, B., Sykes, J., and Sykes, L. R. (1968). Seismology and new global tectonics. J. Geophys. Res., 73, 5855-5900.

[28] Jouanne, F., Mugnier, J. L., Pandey, M. R., Gamond, J. F., Le Fort, P., Serrurier, L., Vigny, C. and Avouac, J. P. (1999). Oblique convergence in the Himalaya of Western Nepal deduced from preliminary result of GPS measurements. Geophys. Res. Lett., 26, 1933-1936.

[29] Khattri, K. N., and Tyagi, A. K. (1983). Seismicity patterns in the Himalayan plate boundary and identification of the areas of high seismic potential. Tectonophysics, 96, 281-297, 1983.

[30] Krishnan, M. S. (1982). Geology of India and Burma. CBS Publishers and Distributors, India, 6th Edition, pp. 536.

[31] Le Fort, P. (1975). Himalaya: the collided range: Present knowledge of the continental arc. American J. of Science, 275A, 1-44.

[32] Le Fort, P. (1994). (Ed.) French Earth Science Research in Himalaya Region. Alliance Francaise, pp. 174.

[33] Le Fort, P. (1996). The Himalayan evolution, In: The Tectonic of Asia (Eds. A. Yin and T. M. Harrison), Cambridge Univ. Press, NewYork, 95-109.

[34] Mckenzie, D. P. (1969). Speculation on the consequences and causes of plate motion. Geophys. J. Roy. Astr. Soc., 18, $1-32$.

[35] Molnar, P. and Tapponnier, P. (1977). The collision between India and Eurasia. Sci. Amer., 236(4), 30-41.

[36] Molnar, P. and Tapponnier, P. (1975). Cenozoic tectonics of Asia: effects of continental collision. Science, 189, 419-426.

[37] Molnar, P., and Chen, W. P. (1983). Focal depths and fault plane solutions of earthquakes under the Tibetan plateau. J. Geophys. Res., 88, 1180-1196.

[38] Molnar, P., and Lyon-Caen, H. (1989). Fault plane solutions of earthquakes and active tectonics of the Tibetan Plateau and its margin. Geophys. J. Int., 99, 123-153.

[39] Molnar, P., and Tapponnier, P. (1978). Active tectonics of Tibet, J. Geophysics, 83, 5361-5375, 1978. 
[40] Molnar, P., Chen, W. P., Fitch, T. J., Tapponnier, P., Warsi, W. E. K., and Wu, F. T. (1977). Structure and tectonics of the Himalaya: A brief summary of relevant Geophysical observations, In: Himalaya: Sciences de la Terre, Paris, 269-294.

[41] Molnar, P., Fitch, T. J., and Wu, F. T. (1973). Fault plane solutions of shallow earthquakes and contemporary tectonics in Asia, Earth Planet. Sci. Lett., 19, 101-112.

[42] Nakata, T. (1982). A photogrammetric study on active faults in the Nepal Himalayas. J. Nepal Geol. Soc., Special Issue 2, $67-80$.

[43] Nakata, T. (1989). Active faults of the Himalaya of India and Nepal. Geol. Soc. Am. Special paper 232, 243-264.

[44] Ni, James and Barazangi, M. (1984). Seismotectonics of the Himalayan collision zone: geometry of the underthrusting Indian plate beneath the Himalaya. J. Geophys. Res., 89, 1147-1163.

[45] Oldham, T. (1882). A catalogue of Indian earthquake from earliest time to the end A. D. 1869. Memoir. Geol. Surv. India, 19, 163-215,

[46] Pandey, M. R., and Nicolas, M. (1991). The aftershock sequence of the Udaypur (Nepal) earthquake of August 20, 1988. J. Nepal Geol. Soc., 7, 19-29.

[47] Pandey, M. R. (1985). Seismic model of central and eastern Lesser Himalaya of Nepal. J. Nepal Geol. Soc., 3, 1-11.

[48] Paudyal, H. (2008). Seismicity and seismotectonics of Nepal and its adjoining region. Ph. D. Thesis, Banars Hindu University, Varanasi, India, pp. 163.

[49] Paudyal, H. (2011). Earthquake mechanism and active tectonics of Eastern Nepal Himalayas and vicinity, J. of Rock Mechanics and Tunneling Technology, 17 (1), 13-24.

[50] Paudyal, H. Shanker, D. H. N. Singh, and V. P. Singh (2009). Application of time- and magnitude-predictable model in the Central Himalaya and vicinity for estimation of seismic hazard. Acta Geod. Geophy. Hung., Vol. 44 (2), 213-226.

[51] Paudyal, Harihar, and Singh, H. N. (2008). Seismicity of Nepal Himalaya and its adjoining regions: recent perspective. J. Scientific Res., 52, 19-31.

[52] Paudyal, Harihar, D. Shanker, H. N. Singh, A. Kumar, A. Panthi, and V. P. Singh (2010). Current understanding of the seismotectonics of Western Nepal Himalaya and vicinity. Acta Geod. Geophy. Hung. Vol. 45 (2), 195-209. doi: 10.1556/ AGeod. 45. 2010.2.5

[53] Paudyal, Harihar, Singh, H. N., Shanker, D., and Singh, V. P. (2008). Stress pattern in two seismogenic sources in Nepal-Himalaya and its vicinity. Acta Geophysica, 56 (2), 313-323, doi: 10.2478/ s11600-008-00013-2.

[54] Powell, C. M., and Conaghan, P. J. (1973). Plate tectonics and the Himalayas. Earth Planet. Sci. Lett., 20, 1-12.

[55] Prasad, B. R., Simon L. Klemperer, Rao V. Vijaya, Tewari, H.C., Khare, Prakash (2011). Crustal structure beneath the Sub-Himalayan fold-thrust belt, Kangra recess, northwest India, from seismic reflection profiling: Implications for Late Paleoproterozoic orogenesis and modern earthquake hazard. Earth and Planet. Science Lett., 308, 218-228.
[56] Rajendran, K., Talwani, P., and Gupta, H. K. (1992). State of stress in the Indian subcontinent: A review. Current Science, $62,86-93$

[57] Rastogi, B. K. (1974). Earthquake Mechanism and plate tectonics in Himalayan region. Tectonophysics, 21, 47-56.

[58] Schelling, D. and Arita, K. (1991). Thrusts tectonics, crustal shortening and structure of the far eastern Nepal Himalaya. Tectonics, 10, 851-862.

[59] Seeber, L., Armbruster, J. G., and Quittmeyer, R. (1981). Seismicity and continental subduction in the Himalayan arc. In: Zagros, Hindukush, Himalaya, Geodynamic Evolution, Geodyanamic Ser. Vol, 3., (Ed. H. K. Gupta and F. Delany), AGU, Washington D. C., 215-242.

[60] Sekiya, H. (1977). Anomalous seismic activity and earthquake prediction. J. Phys. Earth, 25, Suppl., S85-S93.

[61] Shankar, D., Singh, H. N., and Singh, V. P. (1995). Anomalous seismic activity and long-range earthquake prediction in Himachal Pradesh, India. Acta Geod. Geoph. Hung., $30(2-4), 379-395$

[62] Shanker, D., and Papadimitriou, E. E. (2004). Regional timepredictable modeling in the Hindukush-Pamir-Himalayas region. Tectonophysics, 390, 129-140.

[63] Shanker, D., H. N. Singh, H. Paudyal, A. Kumar, A. Panthi, and V. P. Singh (2010). Searching for an Earthquake Precursor- A Case Study of Precursory Swarm as a Real Seismic Pattern before Major Shocks. Pure and Applied Geophysics, 167(6-7), 655-666, DOI 10.1007/ s00024- 0100067-3.

[64] Shanker, D., Kapur, N., and Singh, B. (2002). Thrust wedge mechanics and coeval development of normal and reverse fault in the Himalayas. J. Geol. Soc., London, 159, 264-273.

[65] Sharma, C. K. (1990). Geology of Nepal Himalaya and Adjacent Countries. Mary Martin Booksellers, Kathmandu, Nepal, pp. 479.

[66] Singh, D. D. (2000). Seismotectonics of the Himalaya and its vicinity from centroid moment tensor (CMT) solution of earthquakes. J. Geodynamics, 30, 507-537.

[67] Singh, D. D., and Gupta, H. K. (1980). Source dynamics of two great earthquakes of Indian subcontinent- the Bihar Jan. 15, 1934 and Quetta earthquake of May 30, 1935. Bull. Seismo. Soc. Am., 70, 757-773.

[68] Singh, H. N., H. Paudyal, D. Shanker, A. Panthi, A. Kumar, and V. P. Singh (2010). Anomalous Seismicity and Earthquake Forecast in Western Nepal Himalaya and its Adjoining Indian Region. Pure and Applied Geophysics Vol. 167 (6) 667-684, DOI 10.1007/s00024-010-0072-6.

[69] Singh, H. N., Shanker D. and Singh, V. P. (2005). Occurrence of anomalous seismic activity preceding large to great earthquakes in northeast India region with special reference to 06 August 1988. Physics of the Earth and Planetary Interiors, 148, 561-284.

[70] Singh, V. P., and Shanker, D. (1993). Flow of the Tibetan plateau and tectonics along the Burmese arc. Geophysical Transactions, 38, 135-149. 
[71] Singh, V. P., and Singh, H. N. (1984). Precursory swarm and Medium size earthquake occurrences in Pamirs and its adjoining regions. Earthquake Prediction Res., 2, 245-258.

[72] Singh, V. P., Singh, H. N., and Singh J. (1982). On the possibilities of premonitory swarms for three sequences of Earthquakes of Burma-Szechwan region. Tectonophysics, 85, T21-T29.

[73] Si-Yu, W., and Xiao-Yue, D. (1989). Geothermal activity, geophysical anomalies and the geothermal state of the crust and upper mantle in the Yarlung Zangbo river zone. Tectonophysics, 159, 247-254.

[74] Stökline, J. (1980). Geology of Nepal and its regional frame. J. Geophys. Soc. London, 137, 1-34.

[75] Tandon, A. N., and Srivastava, H. N. (1975). Focal Mechanism of some recent Himalayan earthquakes and regional plate tectonics. Bull. Seismo. Soc. Am., 65, 963-969.

[76] Tapponnier, P., Mercier, J. L., Armijo, R., Han, T. and Zhou, J. (1981). Field evidence for active normal faulting in Tibet. Nature, 294, 410-414.

[77] Upreti, B. N. (1999). An overview of the stratigraphy and tectonics of the Nepal Himalaya. J. Asian Earth Sciences, 17, 577-606.

[78] Valdiya, K. S. (1976). Himalaya transverse faults and their parallesim with subsurface structures of North Indian planes. Tectonophysics, 32, 353-386.

[79] Valdiya, K. S. (1981). Tectonics of the crustal sector of the Himalaya, In Zagros, Hindu Kush, Himalaya, Geodynamic Evolution, Geodynamic Ser. Vol, 3., (Ed. H. K. Gupta, and F. Delany), AGU, Washington D. C., 87-110.
[80] Valdiya, K. S. (1988). Tectonics and evolution of the central sector of the Himalaya. Trans. R. Soc. London, A326, 151-174.

[81] Verma, R. K. (1991). Geodynamics of the Indian Peninsula and the Indian Plate Margin. Oxford and IBH Publishing Co. Pvt. Ltd., New Delhi, pp.374.

[82] Verma, R. K., and Kumar, G. V. R. K. (1987). Seismicity and nature of the plate movement along the Himalayan arc, North east India and Arakan Yoma: a review. Tectonophysics, 134, 157-175.

[83] Verma, R. K., and Reddy, Y. S. K. (1988). Seismicity, focal mechanism and their correlation with the geological/ tectonic history of the Tibetan Plateau. Tectonophysics, 156, 107-131.

[84] Wadia, D. N. (1975). Geology of India. Tata McGraw Hill, New Delhi, 4th Edition, pp. 508.

[85] Yadav, R. B. S., D. Shanker, S. Chopra, A. P. Singh (2010). An application of regional time and magnitude predictable model for long-term earthquake prediction in the vicinity of October 8, 2005 Kashmir Himalaya earthquake. Journal of Natural Hazard .54(3), 985-1014.

[86] Yin, A., and Harrison, T. M. (2006). Geologic evolution of the Himalayan-Tibetan orogen. Annu. Rev. Earth Planet Sci., 28, 211-280.

[87] Zhu, L. P., and Helmberger, D. V. (1996). Intermediate depth earthquakes beneath the India-Tibet Collision zone. Geophys. Res. Lett., 23, 435-438. 